$\xi=$ 离

\title{
Factors influence abroad or home post graduates training among medical students: experience from Sudan
}

\author{
Mohamed Daffalla A. Gismalla ${ }^{1 *}$, Ahmed Abdurrahman Abdallah ${ }^{1}$, \\ Mohammed Alnoor Mohammed ${ }^{2}$, Sami Mahjoub Taha ${ }^{2}$ \\ ${ }^{1}$ Department of surgery, Faculty of Medicine, Gezira University Sudan \\ ${ }^{2}$ Medical student, Faculty of medicine, Gezira University, Sudan \\ *Corresponding author E-mail: mohadaff22@gmail.com
}

\begin{abstract}
Backgrounds: Commonly, doctors migrate for postgraduate study in African and Middle-east countries to western countries. In this study, we would like to know the percentage of graduates who intended to study abroad and determine the factors of their traveling. Material and methods: This is cross-sectional questionnaire survey. Medical students were asked about their future specialty preference, reasons, and site of training. Also, some demographic data were collected. The data was analyzed by SPSS. P value of < 0.05 was considered significant.

Result and Discussion: 197 students responded to our survey and filled the questionnaire properly. Participants knew about future specialty from the teacher, the internet, senior college and advice from a family member with rate $83(42.1 \%), 42(22.8 \%), 41(21.3 \%)$, and $27(13.7 \%)$ respectively. One hundred five $(53.3 \%)$ of the responders preferred to get their specialty training outside Sudan while the remainder 92(46.7\%) preferred local training.

The commonest specialty selected among both group are medicine and surgery respectively. Obstetrics and gynecology are selected mainly among students who prefer local training 14 out of 15 totally, with statistically significant ( $\mathrm{p}$-value $=0.0001$ ). Residency has significant related to the site of training with ( $\mathrm{P}$ value 0.03 ). International recognition and advanced facilities are the commonest cause of traveling abroad among the students. While free hands on training and social reasons are the most common causes of home postgraduates training.

Conclusion: More than fifty percent of the participant prefers abroad post-graduates training. The factors which influents site training can be defined as "Pull and Push" factors.
\end{abstract}

Keywords: Study Abroad; Postgraduates; Medical Students.

\section{Introduction}

Medical students challenged a lot of difficulties to choose their future specialty career. Also, they found troubles to select location or site which provide suitable post-graduates training (Blissett et al 2011). Determining the outlines of career choices among medical students is important for instructors and policy-makers to plan country need of specialists and training vacancies for joiner doctors (Aslam et al 2011). Post graduates medical students specialty selection can affect the supply of physician in any country and also cause a problem when their selection does not match the real need (Cooper et al 2002) (Fisher et al 2003).

In Sudan, medical graduates can start their higher training locally (home) in Sudan Medical specialization board (SMSB). SMSB is the governor body which provides specialized training in most of the specialties. More than 32 patches were graduated from SMSB since its establishments. Also, Sudanese graduates went abroad seeking higher abroad training outside Sudan. Historically, the Sudanese doctors get their postgraduates training in the United Kingdom and Ireland. Besides these countries also they choose to study in Malaysia, Egypt, and Jordan.

Medical students in developing countries prefer to study abroad where the specialty and facility are not found in their home country (Rao et al 2006). In Sudan, $60 \%$ of the registered doctors in
Sudan Medical counsel in 2012 are migrated and working abroad outside Sudan. This migration can be for training or job pursuing (Altbach 2004). Though, the medical students are intended to go abroad for postgraduate study as same as their looking for the good financial situation (Abdalla 2012).

In this study, we would like to determine the ratio of students prefer abroad training versus local training. Also, we would like to highlight the factors influence this desire.

\section{Material and methods}

\subsection{Overview}

This is a descriptive cross-sectional survey conducted in March and April 2016 at the Faculty of Medicine, University of Gezira, Sudan. A self-administered questionnaire distributed to 476 students (forth \& fifth year students) concerning their opinions about future choosing specialties. The questionnaire included questions exploring demographic background characteristics and factors that influence the decision of selecting specialty. We also asked them about their preferable site or location of specialty. The Faculty of Medicine, University of Gezira (FMUG) was established in 1975 in Wad Medani, the Capital of Gezira State. It is the second oldest medical college in Sudan. FMUG is the first school adopting the 
community oriented, community based and problem-solving strategies in the country and is a pioneer in this innovative type of education all over the globe. Curriculum is divided to 10 semesters among 5 years. These semesters divided to 3 phases, basic and introduction phase courses, body region system courses phase, and clerk-ship courses phase.

\subsection{Participant they were clerk-ship students}

They are on semester 8 and 10 (final and semifinal students). They had some experiences and exposure to many specialties. They were divided to three groups' surgery, medicine and obstetrics and gynecology. We distribute the questionnaire at the end of lectures. Informed and written consents obtain from students to participate in the study.

\subsection{Statistical analysis}

The collected data were computerized and statistically analysed using SPSS (statistical package for social science) version 19 Descriptive statistics were used to quantify the categorical variables. Chi square was calculated to compare between specialties selected by students and gender and reasons (Factors) to select specialty. $\mathrm{P}$ value of $<0.05$ was considered significant. An informed consent was obtained from all participants.

\section{Result}

Total number of participants included in this survey was 476 students. They were studying final clerkships semesters $\left(4^{\text {th }} \& 5^{\text {th }}\right)$ year's students. A total of 476 questionnaires were distributed among the participants, the response rate was $53.4 \%$ (254 students responded to the questionnaire), 197 of them were included in the study sample and the dropout were 57 students (questionnaires were filled in proper way by $41.4 \%$ ). General characteristics of the respondents were obtained like gender, marital status, residency, level of students ( $4^{\text {th }}$ or $5^{\text {th }}$ years) and presence of a doctor in the family (Table 1).

Among the participants in this survey more than half of students prefer abroad training $105(53.3 \%)$ to get their post-graduates training. The percentage of participants who prefer local training in Sudan is $92(46.7 \%)$. Specialties selection among both groups is shown in (Table 2). The commonest specialty selected among both group are medicine and surgery respectively. Among students who prefer abroad training Medicine and surgery were selected with rate of 53(50.47\%) 32(30.47\%) respectively. While, between stu- dents who prefer local training medicine and surgery selected by $38(40.30 \%)$ and $24(26.08 \%)$. Obstetrics and gynecology is selected mainly among students who prefer local training 14 out of 15 totally, with statistically significant $(\mathrm{p}$ value $=0.0001)$.

Table 1: Students Characteristics

\begin{tabular}{|c|c|c|c|c|c|}
\hline & & Total & local & Abroad & $\begin{array}{l}\mathrm{P} \\
\text { value }\end{array}$ \\
\hline \multirow[t]{2}{*}{ Sex } & Male & 78 & 32 & 46 & 0.19 \\
\hline & Female & 119 & 60 & 59 & \\
\hline \multirow[t]{2}{*}{ patch } & patch 33 & 86 & 34 & 52 & 0.07 \\
\hline & patch 34 & 111 & 58 & 53 & \\
\hline \multirow[t]{2}{*}{ Marital Status } & Married & 7 & 4 & 3 & 0.57 \\
\hline & Not married & 190 & 88 & 102 & \\
\hline \multirow[t]{2}{*}{ Residence } & Sudan & 174 & 86 & 88 & 0.03 \\
\hline & $\begin{array}{l}\text { Outside } \\
\text { Sudan }\end{array}$ & 23 & 6 & 17 & \\
\hline \multirow{2}{*}{$\begin{array}{l}\text { Does one of your } \\
\text { family doctor }\end{array}$} & yes & 46 & 36 & 82 & 0.51 \\
\hline & no & 55 & 58 & 113 & \\
\hline \multirow{4}{*}{$\begin{array}{l}\text { How you know about } \\
\text { favorite specialty }\end{array}$} & $\begin{array}{l}\text { senior col- } \\
\text { lege }\end{array}$ & 42 & 23 & 19 & \\
\hline & internet & 45 & 9 & 36 & \\
\hline & $\begin{array}{l}\text { advice from } \\
\text { family }\end{array}$ & 27 & 16 & 11 & \\
\hline & your teacher & 83 & 44 & 39 & \\
\hline
\end{tabular}

Table 2: Specialty Selection among Students

\begin{tabular}{lllll}
\multicolumn{5}{c}{ Table 2: Specialty Selection among Students } \\
& $\begin{array}{l}\text { local training } \\
\text { Sudan }\end{array}$ & $\begin{array}{l}\text { Abroad train- } \\
\text { ing }\end{array}$ & Total & $\begin{array}{l}\text { P } \\
\text { value }\end{array}$ \\
\hline $\begin{array}{l}\text { Medicine } \\
\text { Surgery }\end{array}$ & $38(40.30 \%)$ & $53(50.47 \%)$ & 91 & 0.25 \\
Obstetric \& & $24(26.08 \%)$ & $32(30.47 \%)$ & 56 & 0.52 \\
gynae & 14 & 1 & 15 & 0.0001 \\
pediatrics & 15 & 12 & 27 & 0.40 \\
Radiology & 1 & 1 & 2 & \\
Pathology & 1 & 1 & 2 & \\
Family Physi- & 3 & 1 & 4 & \\
cian & 1 & 3 & 4 & \\
Basic science & 1 & 1 & 2 & \\
Anaesthesia & 92 & 105 & 197 & \\
Total & & & & \\
\hline
\end{tabular}

Factors effecting selecting specialties were related to abroad versus local training are shown in (Fig.1). Personal satisfaction and helping community is the leading factors to select specialty among both groups. Factors which influence abroad or local training were shown in (Fig 2 and 3). International recognition and advanced facilities are the commonest cause of travelling abroad among the students. While free hands on training and social reasons are the most common causes of home postgraduates training.

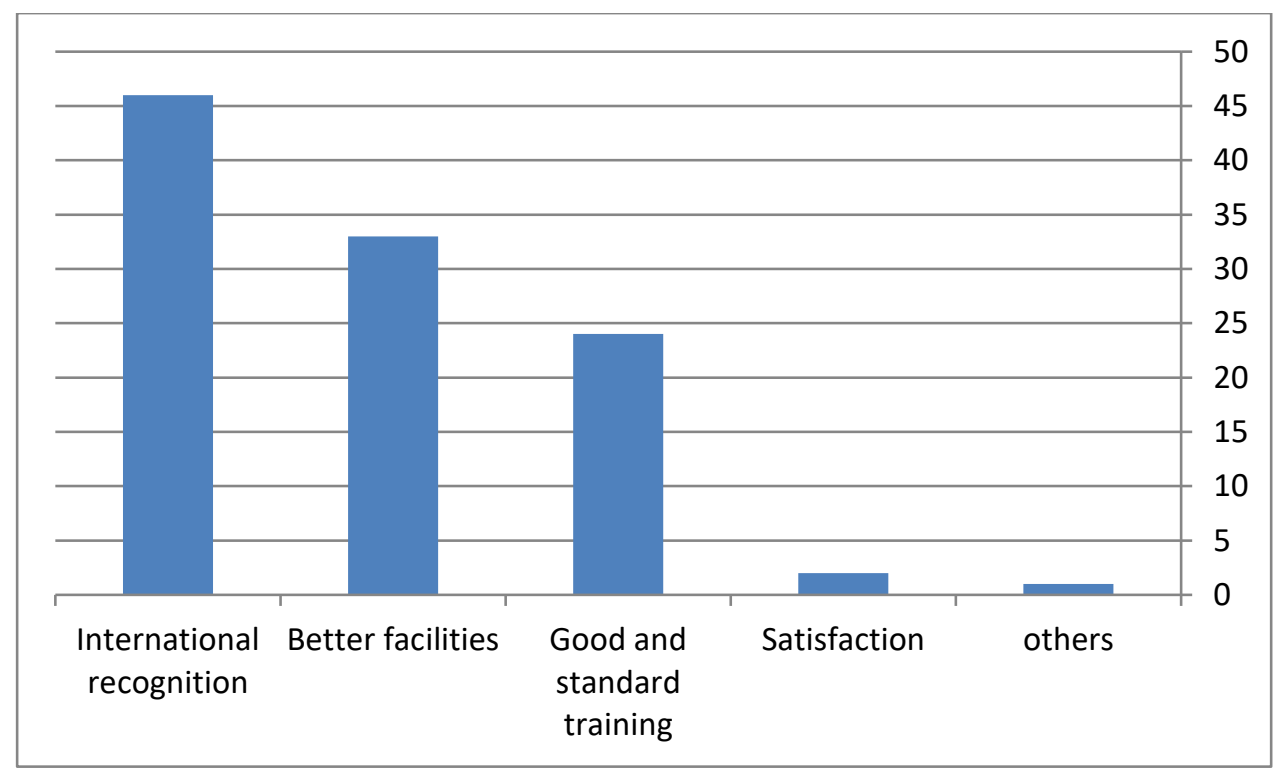

Fig. 1: Factors which Influence Overseas Postgraduates Training. 


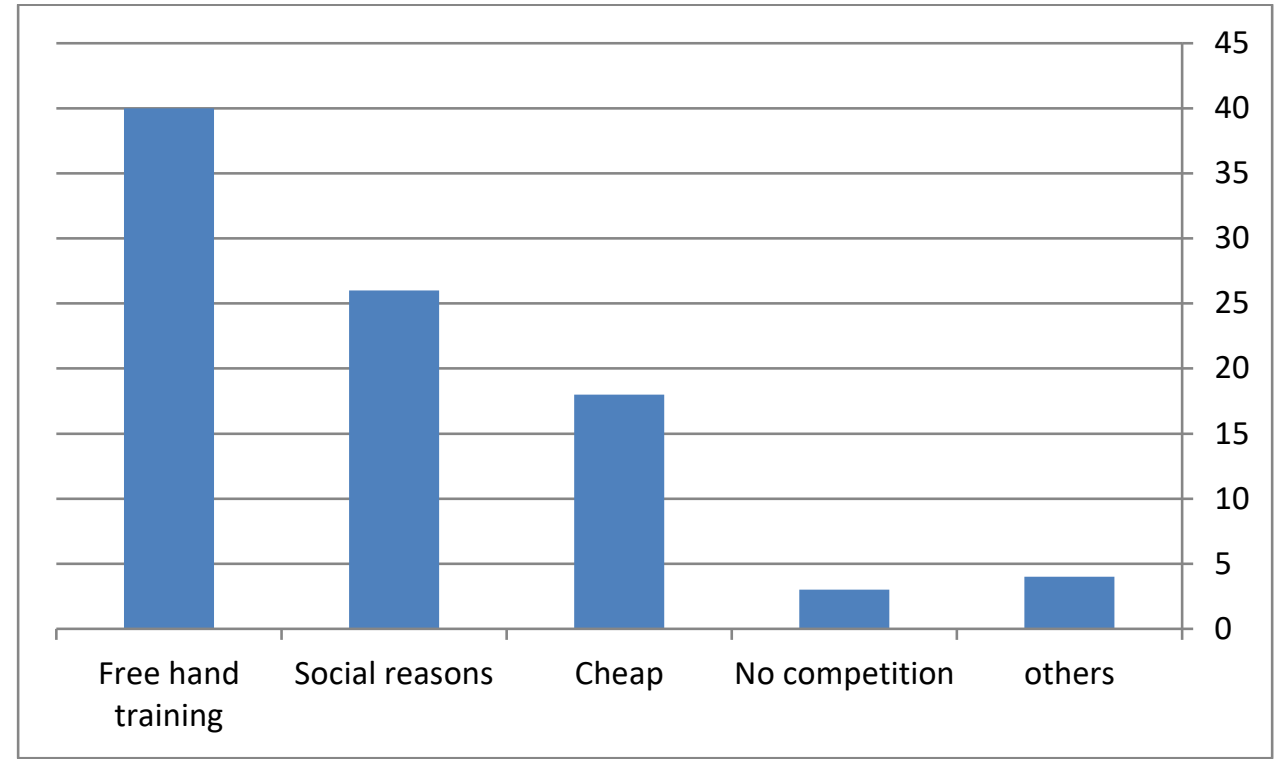

Fig. 2: Factors Influence Local Postgraduates Training.

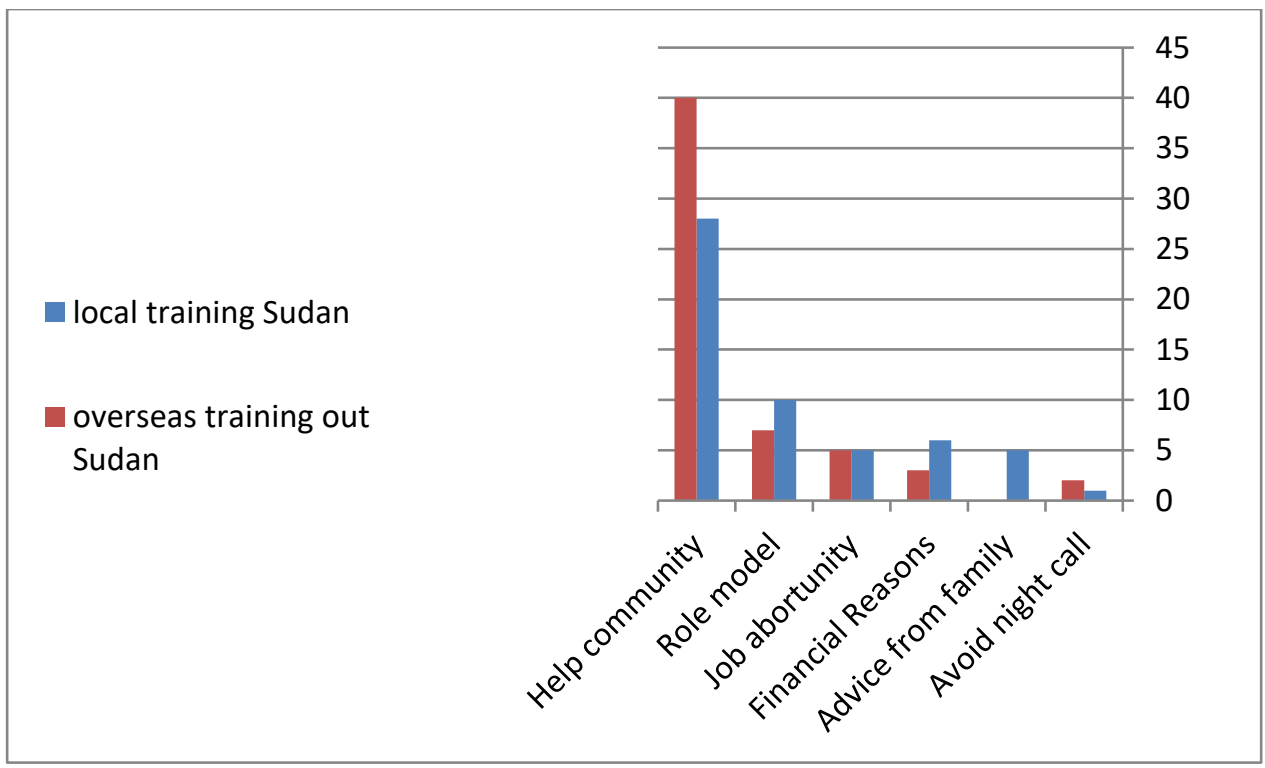

Fig. 3: Factors Influence Specialty Selection to All Participants.

\section{Discussion}

In this study, the percentage of students who prefer to get abroad postgraduates training were $(53.3 \%)$ out of the respondents. So if they go abroad definitely will affect the medical services in the country. This work is less than published data from India in 2004 where $59 \%$ of final year students from Indian medical schools decide to leave India for further abroad training (Mohamed et al 2015). Comparably, it is less than report from New Zealand, where $65 \%$ of students looking for study abroad (Moore et al 2006).

In a study done in Lahore $(60.4 \%)$ of the students intended to train abroad either for a specialty $(54.9 \%)$ or a subspecialty $(5.5 \%)$ while $10 \%$ were not clear about their future intentions (Imran et al 2011). Lastly, it is far less than the result of a study done in Lebanon, which showed $96 \%$ of students prefer to study abroad (Akl et al 2008).

Medicine was the most selected specialty among whole group and each subgroup abroad or local training preference; the same preference was documented in other studies conducted in Iraq and Germany (Yang 2007) (Mpinganjira 2009) (McCarthy et al 2012). Selection of Medicine or others specialties have no statistical significance except obstetric preference. So among students who prefer obstetrics as a future career, the majority of them prefer local training. This can give clue that students prefer local training in obstetrics and gynecology. Also, there was a significant relation between student's residency and the selected place for higher training (inside or outside Sudan). All the students who growth up and studied pre-university learning (partial or complete) outside Sudan they preferred to go abroad for their specialty.

In this study, students prefer local (home) training for many reasons. They think they will get free hand one training. Also, they will not expense mush many similar when going abroad. Lastly, some of them will not go outside (abroad) due to social reasons. In contrast, students prefer to study abroad because they were looking for international recognition, better facility, and good standers training. Students from midland China study abroad in Australia because they looking for recognize center in their home country (Al-Mendalawi 2012).

Many international African students perceived higher qualification in South Africa to get this international recognition (Gibis et al 2012). Canadian students prefer to study abroad in the United States because of that qualification is recognized in their home country (Götz et al 2011). All these factors which affect abroad of home training can be considered as Pull or Push Factors. It is either makes you stay home or select going abroad for further training. 
One of the limitations of the study that it is subjective study, not represent the actual situation. We need to follow this group in future to know what happened to them.

\section{References}

[1] Abdalla I M (2012) National Human Resources for Health Strategic Plan for Sudan 2012-2016. Federal ministry of health.

[2] Akl E A, Maroun N, Major S, Afif C, Abdo A, Choucair J, Sakr M, Li C K, Grant B J and Schünemann H J (2008) Post-graduation migration intentions of students of Lebanese medical schools: a survey study. BMC public health, $8(1), \quad$ p.191. https://doi.org/10.1186/1471-2458-8-191.

[3] Al-Mendalawi M D (2010) Specialty preferences of Iraqi medical students. The clinical teacher, 7(3), pp.175-179. https://doi.org/10.1111/j.1743-498X.2010.00358.x.

[4] Aslam M, Ali A, Taj T, Badar N, Mirza W, Ammar A, Muzaffar S and Kauten J R( 2011) Specialty choices of medical students and house officers in Karachi, Pakistan. East Mediterr Health J. (1), pp74-79 http://www.who.int/iris/handle/10665/118082.

[5] Altbach P G (2004) Higher education crosses borders: Can the United States remain the top destination for foreign students? Change: the magazine of higher learning, 36(2), pp.18-25. https://doi.org/10.1080/00091380409604964.

[6] Blissett S, Law C, Morra D and Ginsburg S (2011) the relative influence of available resources during the residency match: a national survey of Canadian medical students. Journal of graduate medical education. 3(4). pp.497-502. https://doi.org/10.4300/JGME-D11-00043.1.

[7] Cooper R A, Getzen T E, McKee H J and Laud P( 2002) Economic and demographic trends signal an impending physician shortage. Health Affairs, 21(1), pp.140-154 https://doi.org/10.1377/hlthaff.21.1.140.

[8] Fisher E S, Wennberg D E, Stukel T A, Gottlieb D J, Lucas F L and Pinder E L (2003)The implications of regional variations in Medicare spending. Part 2: health outcomes and satisfaction with care. Annals of internal medicine,138(4), pp.288-298. https://doi.org/10.7326/0003-4819-138-4-200302180-00007.

[9] Gibis B, Heinz A, Jacob R and Müller CH (2012) The career expectations of medical students: findings of a nationwide survey in Germany. Dtsch Arztebl Int, 109(18), pp.327-32. DOI: 10.3238/arztebl.2012.0735a

[10] Götz K, Miksch A, Hermann K, Loh A, Kiolbassa K, Joos S and Steinhäuser J( 2011) Aspirations of medical students:" planning for a secure career"-results of an online-survey among students at five medical schools in Germany. Deutsche medizinische Wochenschrift (1946), 136(6), pp.253-257 https://doi.org/10.1055/s-00311272520.

[11] Imran N, Azeem Z, Haider I I, Amjad N and Bhatti M R (2011) Brain drain: post-graduation migration intentions and the influencing factors among medical graduates from Lahore, Pakistan. BMC research notes, 4(1), p.417. https://doi.org/10.1186/1756-0500-4417.

[12] Rao N R, Rao U K and Cooper R A (2006) Indian medical students' views on immigration for training and practice. Academic Medicine, 81(2), pp.185-188. https://doi.org/10.1097/00001888200602000-00020.

[13] Yang M (2007) what attracts mainland Chinese students to Australian higher education. Studies in Learning, Evaluation, Innovation and Development, 4(2), pp.1-12.

[14] Mpinganjira, M., 2009. Comparative analysis of factors influencing the decision to study abroad. African Journal of Business Management, 3(8), p.358

[15] McCarthy E E, Sen A K and Fox Garrity B (2012) Factors that influence Canadian students' choice of higher education institutions in the United States. 2012, 4: 85-95.

[16] Mohamed E Y, Balla S, Abdulaal A, Albary M A and Mukhtar AM (2015) Post-graduation migration intensions of medical students in faculty of medicine, University of Khartoum. 4(4), PP 26 33

[17] Moore J, Gale J, DewK and Simmers D (2006) Student debt amongst junior doctors in New Zealand; part 2: effects on intentions and workforce. The New Zealand Medical Journal (Online), 119(1229). http://www.nzma.org.nz/journal/119$1229 / 1854 /$ 